\begin{tabular}{l|l|l} 
Jurnal Eksplorasi Akuntansi & Vol. 1, No 4, Seri C, November 2019, Hal 1916-1932
\end{tabular} \mid $\begin{aligned} & \text { ISSN : 2656-3649 (Online) } \\
& \text { http://jea.ppj.unp.ac.id/index.php/jea/issue/view/16 }\end{aligned}$

\title{
PENGARUH INFORMASI INVESTASI DAN OVERCONFIDENCE TERHADAP ESKALASI KOMITMEN
}

\author{
Annisa Rysdi Edfa', Sany Dwita ${ }^{2}$ \\ ${ }^{1}$ Alumni Jurusan Akuntansi Fakultas Ekonomi, Universitas Negeri Padang \\ ${ }^{2}$ Jurusan Akuntansi Fakultas Ekonomi, Universitas Negeri Padang \\ *Korespondensi: era97an@gmail.com
}

\begin{abstract}
This study aims to examine the effect of investment information and overconfidence in the commitment escalation. The population in this study were students of the Master Program in the Faculty of Economics, Padang State University. A total of 64 people agreed in this study. The hypothesis of this study is managers who experience negative investment information will tend to escalate commitments than managers who receive positive investment information managers with overconfidence will tend to escalate commitments than managers with underconfidence. Laboratory experiments with a $2 x 2$ factorial design were carried out. 64 MM and MPdE students-as proxies of project managersparticipate in an experiment. One-way ANOVA is used at Hypothesis test. Results that showed significant investment information on the escalation of commitments with a significance value of the One Way ANOVA analysis test of $0.00<0.05$. Overconfidence does not affect managers' decisions in escalating commitments in this study. The significance value of the One Way ANOVA analysis test was 0.74>0.05.
\end{abstract}

Keyword: Investment Information; Overconfidence; Escalation of Commitment

How to cite (APA $6^{\text {th }}$ style)

Edfa, A. R \& Dwita, S. (2019). Pengaruh Informasi Investasi dan Overconfidence terhadap Eskalasi Komitmen. Jurnal Eksplorasi Akuntansi, 1(4), Seri C, 1916-1932.

\section{PENDAHULUAN}

Perusahaan sering kali melakukan investasi dalam berbagai bentuk untuk mendapatkan keuntungan di masa depan. Salah satu keputusan investasi yang dilakukan adalah melaksanakan proyek. Pelaksanaan proyek bisa seperti pembangunan pabrik, pembuatan jalan raya atau kereta api, pendirian gedung-gedung sekolah dan pelatihan, dan sebagainya. Suatu proyek dapat diselenggarakan oleh instansi pemerintah, perusahaan, organisasi sosial maupun oleh perorangan.

Eskalasi komitmen diartikan sebagai fenomena yang menjelaskan bahwa seseorang memutuskan untuk meningkatkan atau menambah investasi lebih besar ke dalam suatu proyek yang sedang dijalankan, meskipun bukti baru memberikan hasil negatif dan keputusan yang telah diambil tersebut salah (Santoso, 2012; Ronay et al., 2016). Menurut Koroy (2008), secara rasional, manajer akan meneruskan proyek yang memberikan keuntungan dan bukan melanjutkan sebuah proyek yang gagal. Contoh kasus eskalasi komitmen yang terjadi di Indonesia seperti pelaksanaan mega proyek Pengembangan Prestasi Olahraga Nasional di Hambalang yang telah menghabiskan uang negara. Pada tahun 2011, proyek tersebut mengalami 
longsor yang menimpa sebagian bangunan di proyek Hambalang. Hal tersebut disebabkan karena kondisi tanah yang bersifat rapuh dan tidak layak untuk dilakukan pembangunan (GresNews.com).

Para pembuat keputusan dari proyek Hambalang menghadapi situasi yang tidak menyenangkan, karena Kemenpora dihadapkan pada keinginan yang bertentangan dalam situasi yang sulit. Di satu sisi, mereka ingin melanjutkan proyek mengingat pengeluaran yang telah terjadi dan sejumlah bangunan yang sudah ada di Hambalang tidak mungkin dihapuskan karena telah menjadi aset negara. Di sisi lain, para pembuat keputusan proyek Hambalang juga mempertimbangkan sejumlah umpan balik negatif dari proyek, salah satunya yaitu masalah struktur tanah di Hambalang yang menyebabkan proyek tersebut tidak layak dilanjutkan. Namun, Kemenpora memilih untuk tetap meneruskan proyek Hambalang hingga proyek tersebut mangkrak di tahun 2012. Proyek Hambalang ada kemungkinan untuk dilanjutkan dengan menambah investasi, namun pembangunan tersebut tidak akan sesuai dengan rencana pemanfaatan awal (CNBC Indonesia). Masalah Hambalang merupakan salah satu situasi eskalasi komitmen dimana sumber daya yang sebelumnya diinvestasikan seperti uang, waktu, atau usaha tidak memberikan hasil yang positif, dan terdapat ketidakpastian apakah investasi tambahan akan menghasilkan kesuksesan (Brockner, 1992; Staw, 1976).

Hasil beberapa penelitian terdahulu telah menunjukkan bukti bahwa manajer yang membuat keputusan untuk memulai sebuah proyek dan kemudian proyek tersebut tidak menguntungkan akan cenderung meneruskan proyek dengan meningkatkan komitmennya atas proyek tersebut (Staw, 1976; Harrell dan Harrison, 1994; Liang et al., 2014). Brockner (1992) berpendapat bahwa self-justification theory adalah teori yang bisa menjelaskan perilaku eskalasi komitmen pada tingkat pengambilan keputusan individu. Teori ini menjelaskan bahwa seseorang akan melakukan pembenaran atas keputusan yang sudah diambil meskipun hasilnya tidak sesuai harapan demi kepentingan harga diri atau citra semata. Dampaknya, tanggung jawab individu untuk memulai proyek yang tidak menguntungkan menciptakan motif pembenaran diri. Sehingga manajer bertahan dan tetap melanjutkan proyek (Chang et al., 2018).

Investigasi terhadap fenomena eskalasi komitmen diperlukan oleh organisasi karena perilaku tersebut bisa menyebabkan kerugian ekonomi yang besar. Imbas dari perilaku eskalasi komitmen tentu akan membahayakan. Kerugian ekonomi yang besar bisa berujung pada kebangkrutan sebuah organisasi (Dwita, 2007; Tine, 2013; Jackson et al., 2018). Hal ini membuat peneliti tertarik untuk meneliti tentang faktor yang menyebabkan eskalasi komitmen. Penelitian ini diharapkan memberikan masukan dan memberikan hasil yang jelas tentang faktor apa saja yang mempengaruhi eskalasi komitmen.

Faktor pertama yang menyebabkan terjadinya eskalasi komitmen dalam penelitian ini yaitu adanya informasi investasi negatif. Berdasarkan penelitian terdahulu terhadap eskalasi komitmen mengenai pengaruh framing negatif atas informasi investasi, menunjukkan hasil penelitian yang belum konsisten (Sharp dan Salter, 2004; Dwita, 2007; Rita dan Sari, 2012; Dewanti, 2010; Amelia, 2014; Sari dan Wirakusuma, 2016; Nasution, 2018). Penelitian ini mencoba menguji kembali pengaruh informasi investasi negatif terhadap eskalasi komitmen apakah dengan menggunakan teori yang sama akan memberikan hasil yang sama dengan penelitian terdahulu. Dimensi waktu mengakibatkan adanya perubahan pola pikir manusia sehingga ada kemungkinan keputusan yang dihasilkan juga berbeda (Sari dan Wirakusuma, 2016).

Teori prospek memprediksi bahwa cara keputusan digambarkan atau dibingkai memengaruhi pilihan manajer. Manajer akan cenderung bersikap risk taking apabila dihadapkan 
pada informasi investasi negatif dan bersikap risk averse apabila dihadapkan pada informasi investasi positif. Dewanti (2010) mengatakan biaya yang telah dikeluarkan (sunk cost) bertindak sebagai titik referensi bagi manajer dalam membuat keputusan. Jackson et al. (2018) berpendapat bahwa seharusnya ketika menghadapi proyek gagal, tindakan rasional yang dilakukan adalah mengabaikan sumber daya yang sudah diinvestasikan (sunk cost) dan meninggalkan proyek. Faktanya orang akan mempertimbangkan sunk cost dan umumnya membuat pilihan yang tidak rasional yaitu dengan meningkatkan komitmen mereka atas proyek gagal (Conlon dan Garland, 1993 dalam Jackson et al., 2018). Menurut Fokufuka et al. (2014), keberadaan sunk cost adalah motivasi bagi akuntan untuk memberikan laporan yang mendukung kelanjutan proyek yang tidak menguntungkan. Dengan mempertimbangkan sunk cost sebagai acuan pengambilan keputusan yang diikuti dengan ketidakpastian serta pertimbangan terhadap nama baik atas tanggung jawab suatu proyek, mengakibatkan manajer menghadapi masalah eskalasi komitmen (Mulia dkk, 2015).

Selain informasi investasi, overconfidence individu juga diduga akan memengaruhi keputusan manajer melakukan eskalasi komitmen. Penelitian yang menguji pengaruh overconfidence terhadap pengambilan keputusan di Indonesia telah dilakukan dalam bidang keuangan, seperti penelitian penilaian saham (Kufepaksi, 2010), strategi perdagangan saham (Trinugroho dan Sembel, 2011), keputusan investasi (Almilia dan Wulanditya, 2016), dan pertimbangan auditor (Kartikasari dkk., 2013). Sedangkan penelitian yang telah menguji overconfidence terhadap keputusan untuk melakukan eskalasi komitmen telah dilakukan oleh Ronay et al., (2016) dan Tine (2013). Penelitian tersebut menunjukkan hasil bahwa seseorang dengan tingkat overconfidence tinggi memiliki kecenderungan yang lebih besar untuk meningkatkan komitmen mereka ke arah tindakan yang gagal.

Penelitian yang mencoba menghubungkan karakteristik individu, seperti overconfidence pada pengambilan keputusan eskalasi komitmen masih sedikit ditemukan. Soma dan Restuti (2017) serta Helmayunita (2015) juga telah menyarankan penelitian selanjutnya untuk menguji karakteristik individu dengan hubungannya pada eskalasi komitmen. Hal ini memotivasi peneliti untuk melakukan penelitian dengan menguji pengaruh overconfidence sebagai salah satu faktor penyebab manajer melakukan eskalasi komitmen. Menurut Ronay et al. (2016), ada hubungan intuitif antara kepercayaan diri dengan pengambilan keputusan. Keputusan yang muncul dari tingkat kepercayaan diri yang tinggi (overconfidence) sering membuat pengambil keputusan bertahan dengan keputusan awal mereka, bahkan dalam menghadapi bukti nyata bahwa keputusan awal yang dibuat tersebut menunjukkan kegagalan (Lichtenstein et al., 1982 dalam Tine, 2013; Meikle et al., 2016).

Penelitian ini menguji kembali pengaruh informasi investasi yang diterima manajer, yang menjadi perbedaan adalah penelitian ini mencoba memasukkan variabel karakteristik individu yaitu overconfidence. Overconfidence dalam penelitian ini menggunakan pengukuran yang berbeda dari penelitian lain yaitu dengan menentukan bias skor melalui kuis pengetahuan umum Michailova \& Katter (2014). Penelitian ini bertujuan untuk berkontribusi kepada literatur dengan memeriksa pengaruh informasi investasi dan juga overconfidence pada keputusan melakukan eskalasi komitmen. Penelitian ini diharapkan memberikan gambaran yang jelas serta memperdalam pemahaman tentang pengaruh informasi investasi dan overconfidence dalam kecenderungan melakukan eskalasi komitmen. Pemahaman yang lebih baik mengenai faktorfaktor yang berkontribusi dalam eskalasi komitmen sangat penting bagi perusahaan (Tine, 2013). Pemahaman yang lebih baik akan membantu perusahaan untuk mengatasi masalah eskalasi komitmen serta membuat sumber daya memberikan hasil yang lebih baik. 


\section{REVIU LITERATUR DAN HIPOTESIS}

\section{Teori Perspektif Diri (Self-Justification Theory)}

Self-justification theory merupakan satu teori yang digunakan untuk menjelaskan eskalasi komitmen. Menurut Salter et al. (2013) teori ini mengacu pada disonansi kognitif (Festinger, 1957) dan komitmen psikologis (Kiesler, 1971) untuk menyatakan bahwa pembenaran diri (self justification) adalah proses psikologis penting yang mendasari perilaku eskalasi. Teori ini memberikan penjelasan bahwa saat manajer dihadapkan pada kegagalan suatu proyek, maka manajer akan menigkatkan komitmennya dalam upaya merasionalkan keputusan dari sejumlah tindakan irasional. Dampaknya, tanggung jawab individu untuk memulai proyek yang tidak menguntungkan menciptakan motif pembenaran diri. Mulia (2015) mengatakan meski sejumlah teori yang berbeda juga digunakan untuk menjelaskan fenomena eskalasi komitmen, namun teori self-justification dianggap teori yang paling relevan untuk eskalasi komitmen pada tingkat pembuatan keputusan individu.

Brockner (1992) menyatakan bahwa seorang individu akan lebih cenderung untuk membenarkan keputusan yang telah diambilnya meskipun hasilnya tidak sesuai dengan yang diharapkan untuk kepentingan harga diri atau citra semata. Ketika mendapat umpan balik yang mengindikasikan kerugian atas suatu proyek investasinya, manajer cenderung untuk tetap mempertahankan atau melanjutkan proyek tersebut dengan tujuan untuk mempertahankan harga diri dan juga nama baiknya. Manajer tersebut tidak mau dinilai bahwa dia tidak melakukan analisis pendahuluan atas keputusan yang dipilihnya (Nugraha, 2015).

\section{Teori Prospek (Prospect Theory)}

Teori prospek memberikan penjelasan mengenai terjadinya bias kognitif yang memengaruhi pengambilan keputusan dalam kondisi ketidakpastian dan berisiko (Kahneman dan Tversky, 1979;1981 dalam Eveline, 2010). Teori prospek menyarankan bahwa individu menunjukkan perilaku mencari risiko atau menolak risiko tergantung pada pembingkaian situasi atau masalah tertentu. Perilaku menolak risiko (risk averse) diajukan ke permukaan ketika memilih antara dua alternatif positif. Perilaku pencarian risiko (risk seeking) diajukan ke permukaan ketika individu diharuskan untuk memilih di antara dua alternatif negatif, seperti memilih antara kerugian pasti (misalnya, menghentikan proyek di mana investasi sumber daya yang signifikan telah dikeluarkan) dan kemungkinan lebih besar kerugian (kombinasi dari investasi awal ditambah lebih banyak sumber daya yang dihabiskan) dalam upaya untuk kembali ke titik referensi (Tine, 2013).

Informasi investasi disajikan dalam dua kondisi yaitu posisi untung dan posisi rugi. Informasi yang disajikan dalam posisi menguntungkan cenderung membuat individu berhati-hati untuk setiap pengambilan keputusan. Sedangkan informasi yang disajikan dalam posisi tidak menguntungkan cenderung menunjukkan individu lebih menyukai risiko agar mendapat pengembalian di masa mendatang. Manajer akan memandang keputusan selanjutnya sebagai pilihan keputusan antara kerugian yang pasti terjadi dengan tidak menambah investasi atau kerugian dimasa mendatang yang kurang pasti dengan risiko menambah dana dan berharap mendapat pengembalian positif. Menurut Keil et al dalam Sari dan Wirakusuma (2016) sunk cost mendorong individu berperilaku menyukai risiko yang mengarah pada eskalasi komitmen untuk proyek yang gagal.

Arkes dan Blumer (1985) dalam Fokufuka (2014) mengemukakan bahwa dalam hal manajemen proyek, sunk cost adalah kerugian pasti dan seorang individu akan lebih suka opsi dengan kemungkinan kerugian yang lebih besar, jika masih ada peluang dari hasil yang 
menguntungkan. Maksudnya disini adalah manajer akan membuat keputusan meningkatkan komitmennya pada keadaan informasi negatif atau rugi dengan harapan mendapatkan imbal hasil positif di masa datang. Hubungan antara kesediaan manajemen untuk melanjutkan proyek yang gagal dan keberadaan sunk cost secara empiris diperiksa oleh Garland (1990), yang menemukan bahwa persentase sunk cost yang lebih tinggi dapat mengarah pada kemauan yang lebih besar untuk melanjutkan proyek yang gagal (Fokufuka, 2014).

\section{Eskalasi Komitmen}

Manajer cenderung melakukan perilaku pembenaran diri (self-justification) dengan terus melanjutkan proyek yang berkemungkinan gagal dengan harapan mendapatkan umpan balik positif karena kebutuhan untuk membenarkan keputusan awal untuk menjaga reputasinya (Kelly dan Milkman, 2013 dalam Nasution, 2018). Kegigihan dalam menghadapi umpan balik negatif menjelaskan apa yang dimaksud dengan eskalasi komitmen (Brockner, 1992).

Brockner (1992) dan Jackson et a.l (2018) menjelaskan bahwa eskalasi komitmen adalah komitmen berkelanjutan untuk menginvestasikan sumber daya (uang, waktu, dan atau usaha) dalam menghadapi informasi negatif. Definisi dari eskalasi komitmen mencerminkan tiga karakteristik yang menentukan eskalasi komitmen, yaitu; (1) kerugian telah diderita, (2) ada kesempatan untuk bertahan atau menarik diri, dan (3) konsekuensi dari tindakan ini tidak pasti (Staw, 1997 dalam Tine, 2013). Eskalasi komitmen yang tidak rasional (nonrational escalation of commitment) adalah derajat dimana individu meningkatkan komitmen untuk tindakantindakan tertentu yang dilakukan sebelumnya sampai satu titik yang melewati model pengambilan keputusan yang rasional (Bazerman, 1994 dalam Mulia dkk., 2015). Pada akhirnya manajer akan merasa kesulitan dalam memisahkan keputusan yang telah diambil sebelumnya dengan keputusan masa depan. Sehingga dampaknya seorang manajer akan membiaskan keputusannya akibat tindakan masa lalu dan mempunyai tendensi untuk meningkatkan komitmen apabila menerima umpan balik negatif.

Menurut Kreitner dan Kinicki (2005) dalam Nugraha (2015) menyebutkan empat faktor yang menyebabkan terjadinya perilaku eskalasi komitmen, yaitu: faktor penentu psikologis dan sosial, faktor penentu organisasional, karakteristik proyek, dan faktor penentu kontekstual. Faktor psikologis dan sosial merupakan kontributor utama dari eskalasi komitmen yang termasuk didalamnya adalah pertahanan ego dan motivasi individu. Faktor selanjutnya yang mengakibatkan terjadinya situasi eskalasi komitmen adalah faktor penentu organisasional. Dalam faktor penentu organisasional adanya pemutusan komunikasi, politik di dalam organisasi, dan adanya kelambanan organisasional yang menyebabkan organisasi membiarkan terjadinya tindakan yang berdampak buruk bagi perusahaan, atau dengan kata lain mendukung dan menjalankan adanya suatu keputusan yang bereskalasi komitmen. Faktor selanjutnya adalah karakteristik proyek. Karakteristik proyek memasukkan fitur-fitur objektif proyek, yang berdampak paling besar pada keputusan eskalasi komitmen. Faktor yang terakhir yang mengakibatkan terjadinya situasi eskalasi komitmen adalah faktor penentu kontekstual. Faktor ini memberi penjelasan bahwa penyebab terjadinya eskalasi komitmen karena adanya kekuatankekuatan politik dari luar yang berada di luar kendali organisasi.

\section{Informasi Investasi}

Informasi investasi merupakan satu sumber daya yang sangat diperlukan dalam suatu organisasi dengan adanya data yang telah diolah menjadi bentuk yang lebih berguna dan lebih berarti bagi yang menerimanya untuk pengambilan keputusan investasi (Ais Zakiyudin 2012 dalam Restuti 
dan Soma, 2017). Informasi yang diperoleh dapat dijadikan pedoman bagi pengambil keputusan untuk menentukan alternatif pilihan terhadap hal yang sedang dijalankan. Dikaitkan dengan investasi pada perusahaan, informasi mengenai investasi sangat diperlukan secara relevan untuk mengetahui proyek yang sedang dijalankan. Informasi investasi akan dipakai untuk pengambilan keputusan yang dilakukan seorang manajer dengan cara mengetahui kondisi proyek yang sedang dijalankan (Restuti dan Soma, 2017).

Informasi investasi dihadapkan dalam dua kondisi yaitu untung atau informasi positif dan rugi atau informasi negatif. Informasi positif yang disajikan dalam posisi menguntungkan cenderung membuat seseorang berhati-hati untuk setiap pengambilan keputusan. Manajer akan dihadapkan pada pilihan antara untung yang pasti dengan pengembalian investasi yang semula atau keuntungan di masa mendatang yang tidak pasti. Kondisi tersebut menjadikan manajer cenderung menghindari risiko (risk averse) dan mengambil keuntungan yang pasti daripada menghadapi risiko keuntungan yang tidak pasti dengan tidak melanjutkan proyek (Whyte, 1986).

Informasi negatif yang disajikan dalam posisi tidak menguntungkan cenderung menunjukkan seseorang lebih menyukai risiko agar mendapat pengembalian di masa mendatang. Manajer akan memandang keputusan selanjutnya sebagai pilihan keputusan antara kerugian yang pasti terjadi dengan tidak menambah investasi atau kerugian dimasa mendatang yang kurang pasti dengan risiko menambah dana dan berharap mendapat pengembalian positif. Dalam keadaan tersebut, manajer cenderung mengambil risiko (risk seeking) dengan memilih kerugian yang tidak pasti yang memberikan harapan perbaikan dengan komitmen menambah dana. Manajer akan memandang keputusan selanjutnya sebagai pilihan keputusan antara kerugian yang pasti terjadi dengan tidak menambah investasi atau kerugian dimasa mendatang yang kurang pasti dengan risiko menambah dana dan berharap mendapat pengembalian positif.

\section{Overconfidence}

Overconfidence atau kepercayaan diri berlebih adalah keyakinan positif bahwa seorang individu lebih terampil, cerdas, dan mampu daripada yang sebenarnya dimiliki dalam domain atau tugas tertentu (Russo dan Schoemaker, 2016; Kennedy et al., 2013). Secara umum, overconfidence terjadi ketika keyakinan pengambil keputusan tentang kualitas kinerjanya melebihi kinerja aktual (Stone, 1994 dalam Tine, 2013). Bazerman dan Moore (2013) menyebutkan bahwa overconfidence ada tiga, yaitu overprecision, overestimation, dan overplacement.

Overprecision menggambarkan kecenderungan untuk terlalu yakin bahwa penilaian dan keputusan kita akurat, tidak tertarik dalam menguji asumsi kita, dan menolak bukti yang menunjukkan kita mungkin salah. Overestimation adalah kecenderungan umum untuk berpikir kita lebih baik, lebih pintar, lebih cepat, lebih mampu, lebih menarik, atau lebih populer (dan sebagainya) daripada yang sebenarnya. Overplacement adalah kecenderungan untuk berpikir salah bahwa kita memiliki peringkat lebih tinggi daripada yang lain pada dimensi tertentu, terutama dalam konteks kompetitif. Pembuat keputusan dengan tingkat kepercaaan yang lebih tinggi cenderung kurang konsesi dalam keputusan yang mereka buat, yang akibatnya dapat menyebabkan komitmen mereka untuk tindakan sebelumnya (Neale dan Bazerman, 1985 dalam Tine, 2013). Singkatnya, kepercayaan yang berlebihan, adalah bias kognitif yang mempengaruhi kecenderungan untuk meningkatkan komitmen ketika pengambil keputusan melebih-lebihkan tingkat akurasi penilaian mereka terhadap kemampuan mereka untuk menghasilkan hasil yang positif (Schwenk, 1986 dalam Tine, 2013). 


\section{Hubungan Informasi Investasi dengan Eskalasi Komitmen}

Informasi investasi dibedakan dalam dua kondisi yaitu untung yang merupakan informasi positif dan rugi yang merupakan informasi negatif. Kahneman dan Tversky (1979) dalam Mulia (2015) menjelaskan ketika manajer menerima informasi investasi yang negatif dalam bentuk pilihan antara kerugian pasti yang telah terjadi dengan kerugian dimasa mendatang yang kurang pasti, maka manajer cenderung menanggung risiko (risk seeking) dengan memilih meningkatkan komitmennya terhadap sebuah proyek dengan harapan mendapat pengembalian positif.

Sunk cost turut mendorong manajer untuk mempertimbangkan pilihan eskalasi. Whyte (1993) dalam Dwita (2007) menyebutkan bahwa sunk cost mempengaruhi manajer untuk mempertimbangkan informasi investasi yang negatif. Arkes dan Blumer (1985) dan Whyte (1986) mengemukakan bahwa dalam hal manajemen proyek, sunk cost merupakan kerugian pasti dan seorang individu akan menyukai pilihan dengan kemungkinan kerugian dimasa mendatang yang kurang pasti, jika ada peluang untuk mendapatkan kenguntungan di masa depan. Artinya, dukungan untuk pengabaian proyek dianggap sebagai menerima kerugian dengan pasti, sedangkan mendukung kelanjutan proyek dengan eskalasi komitmen dianggap sebagai peluang bahwa kerugian akan dihindari dan mendapatkan peluang keuntungan dimasa datang. Uraian tersebut membawa peneliti pada hipotesis:

H1: Manajer yang menerimana informasi investasi negatif akan cenderung melakukan eskalasi komitmen daripada manajer yang menerima informasi investasi positif.

\section{Hubungan Overconfidence dengan Eskalasi Komitmen}

Overconfidence bisa menyebabkan eskalasi komitmen dengan berbagai cara, seperti melalui proses penilaian probabilitas, kurangnya persepsi risiko, pemrosesan informasi yang tidak akurat, dan kesalahan penilaian pengetahuan di pihak pembuat keputusan (Tine, 2013). Pembuat keputusan yang terlalu percaya diri lebih cenderung untuk mengambil taruhan daripada mencari informasi yang akan meningkatkan pemahaman mereka tentang objek, situasi, atau peristiwa tertentu. Dengan mengabaikan informasi negatif, pembuat keputusan yang terlalu percaya diri cenderung berkomitmen untuk tindakan mereka sebelumnya (Klayman, Soll, Gonzalez-Vallejo, \& Barlas, 1999 dalam Ronay et al., 2016).

Penelitian yang dilakukan oleh Pikulina et al. (2017) menunjukkan hasil bahwa ketika seorang individu dalam tingkat overconfidence tertinggi memilih tingkat investasi tinggi yang tidak tepat dan, juga, individu yang underconfidence memilih investasi rendah yang tidak tepat. Hal ini memberikan penjelasan ketika seorang individu terlalu percaya diri, dia akan keliru dalam mengambil keputusan. Orang yang memiliki kepercayaan diri berlebih tidak mampu mengenali keterbatasan yang dimilikinya sehingga cenderung akan membuat keputusan yang tidak realistis atau bias keputusan dan pilihan strategi yang menyebabkan kegagalan (Kennedy, Anderson \& Moore, 2012 dalam Tine, 2013). Fenomena overconfidence ini membuat seorang manajer untuk lebih mungkin melakukan eskalasi komitmen. Uraian tersebut membawa peneliti pada hipotesis:

H2: Manajer dengan overconfidence akan cenderung melakukan eskalasi komitmen daripada manajer dengan underconfidence.

\section{METODOLOGI PENELITIAN}

\section{Desain Penelitian}

Desain penelitian ini menggunakan desain kuasi eksperimen dengan faktorial $2 \times 2$. Sugiyono (2017) menjelaskan desain kuasi eksperimen merupakan desain yang mempunyai kelompok 
kontrol, tetapi tidak dapat berfungsi secara penuh untuk mengontrol variabel-variabel luar yang dapat mempengaruhi pelaksanaan eksperimen. Tabel 1 berikut menyajikan desain eksperimen yang digunakan untuk penelitian ini.

Tabel 1

Desain Faktorial 2x2

\begin{tabular}{cccc}
\hline & & \multicolumn{2}{c}{ Informasi Investasi } \\
\cline { 2 - 4 } & & Negatif & Positif \\
\hline $\begin{array}{c}\text { Kepercayaan } \\
\text { Diri }\end{array}$ & Overconfidence & EK 1 & EK 2 \\
\cline { 2 - 4 } & Underconfidence & EK 3 & EK 4 \\
\hline
\end{tabular}

Teknik pengambilan sampel yang digunakan dalam penelitian ini adalah total sampling. Teknik ini merupakan teknik pengambilan sampel dengan jumlah sampel sama dengan jumlah populasi. Partisipan pada penelitian ini adalah mahasiswa program Magister Manajemen (MM) dan mahasiswa program Magister Pendidikan Ekonomi (MPdE) Fakultas Ekonomi Universitas Negeri Padang. Sebanyak 64 mahasiswa berpartisipasi dalam eksperimen ini. Mahasiswa dipilih sebagai proksi manajer proyek karena kesulitan dalam mengumpulkan para manajer perusahaan yang sebenarnya.

Teknik pengumpulana data dalam penelitian ini dilakukan dengan membagikan secara langsung kuesioner kepada peserta. Pembagian, pengisian, dan pengembalian kuesioner dilakukan di dalam kelas. Penyebaran kuesioner hanya dilakukan pada mahasiswa yang hadir mengikuti perkuliahan pada saat kuesioner dibagikan. Waktu pendistribusian kuesioner disesuaikan dengan jadwal mata kuliah peserta dengan tujuan tercapainya tingkat pengembalian kuesioner (response rate) yang tinggi.

\section{Instrumen Penelitian}

Instrumen penelitian ini mengadopsi dan memodifikasi dari Sharp dan Salter (1997) untuk variabel informasi investasi dan keputusan melakukan eskalasi komitmen serta Michailova \& Katter (2014) untuk variabel overconfidence. Instrumen overconfidence dikembangkan dari kuesioner Bahasa Inggris asli dengan menggunakan teknik penerjemahan kembali. Dua individu yang berbeda dengan penguasaan Bahasa Inggris dan Bahasa Indonesia yang baik terlibat dalam menerjemahkan kembali kuesioner ini. Metode ini sangat umum digunakan dalam penelitian terdahulu. Tujuan dari penggunaan metode ini adalah untuk memastikan konsistensi makna antara kuesioner asli dengan yang diterjemahkan (Dwita et al., 2018).

Instrumen penelitian ini berisi skenario proyek investasi yang sama, namun diberi perlakuan informasi investasi yang berbeda yaitu informasi investasi negatif dan informasi investasi positif. Partisipan dikondisikan sebagai seorang manajer proyek. Mereka menghadapi masalah yang memaksa mereka untuk memutuskan melanjutkan atau menghentikan proyek yang mereka awasi. Partisipan diberi informasi tentang proyek investasi dalam pembuatan sebuah produk baru berupa produk Bolu Ubi yang sedang dijalankan oleh PT Kue N2. Saat ini proyek yang baru berjalan 2 tahun dan telah menghabiskan dana 4 milyar menunjukkan prospek kegagalan. Ada peluang menyelamatkan proyek dengan tambahan dana 2 milyar. Partisipan selanjutnya diminta untuk membuat keputusan apakah akan menghentikan proyek atau melanjutkan proyek. Perlakuan yang diberikan untuk informasi investasi negatif adalah dengan 
menyajikan kerugian 4 milyar yang pasti terjadi apabila menhentikan proyek atau $67 \%$ kerugian yang belum pasti terjadi apabila melanjutkan proyek. Perlakuan yang diberikan untuk informasi investasi positif adalah dengan menyajikan kemungkinan hemat 2 milyar yang pasti terjadi apabila menghentikan proyek atau 33\% kemungkinan memulihkan investasi 6 milyar (break even) apabila melanjutkan proyek. Selanjutnya partisipan memilih keputusan evaluasi proyek dengan menunjukkan preferensi mereka menggunakan skala likert apakah akan menghentikan proyek atau melanjutkan proyek.

Bagian lain dari instrumen penelitian ini adalah kuis pengetahuan umum untuk mengetahui tingkat overconfidence seseorang, dimana kuesioner dengan perlakuan informasi investasi negatif maupun informasi investasi positif memiliki kuis pengetahuan umum yang sama. Pertanyaan pengetahuan umum yang diberikan berjumlah delapan belas pertanyaan. Setiap pertanyaan pengetahuan umum memiliki tiga jawaban pilihan ganda seperti "Perusahaan apa yang dimiliki Bill Gates? (a) Intel, (b) Microsoft, (c) Dell Computers". Peserta harus menjawab semua pertanyaan pengetahuan umum dengan memilih jawaban yang mereka anggap benar. Peserta kemudian diminta memberikan angka dari 33\% hingga 100\% untuk mencerminkan kepercayaan mereka dalam akurasi jawaban tersebut.

\section{Pilot Test}

Uji coba instrumen (pilot test) dilakukan sebelum kuesioner dibagikan kepada peserta penelitian. Kuesioner diuji terlebih dahulu untuk mengevaluasi apakah peryataan relevan dan mudah dimengerti atau tidak oleh peserta dengan menghitung validitas dan reliabilitas kuesioner uji coba. Uji coba instrumen ini diberikan pada mahasiswa akuntansi tahun masuk 2017 di Universitas Negeri Padang yang tidak termasuk dalam peserta penelitian. Sebanyak 30 orang berpartisipasi pada uji coba ini.

Kuesioner dalam penelitian ini akan diuji kevalidan beserta kereliabilitasnya terhadap masing-masing item pertanyaan yang ada. Dalam pengujian validitas terhadap kuesioner dilakukan dengan menggunakan validitas item. Uji validitas ini menggunakan korelasi Bivariate Pearson (Produk Momen Pearson). Jika nilai Sig. (2-tailed) < 0,05 dan Pearson Correlation bernilai positif, maka instrumen atau item-item pertanyaan berkorelasi signifikan terhadap skor total (dinyatakan valid). Analisis ini dilakukan dengan cara mengkorelasikan masing-masing skor item dengan skor total. Uji validitas ini dilakukan pada 18 pertanyaan pada kuis pengetahuan umum. Kuesioner untuk kasus informasi investasi tidak dapat dicari kevalidan datanya karena merupakan uji manipulasi yang dilakukan oleh peneliti dan hanya mengandung 1 unsur item pernyataan. Dari hasil olah data menggunakan SPSS, didapatkan hasil bahwa nilai Sig. (2-tailed) yang dihasilkan setiap item pertanyaan $<0,05$ yang artinya bahwa tiap item dinyatakan valid.

Sama seperti uji validitas diatas, uji reliabilitas hanya dilakukan pada kuesioner pengetahuan umum dengan hasil Cronbach's Alpha sebesar 0,909. Moss et al. (1993) menyatakan, bahwa nilai koefisien alpha yang dapat diterima secara umum sama dengan 0,6 , namun ambang yang lebih dikenal yaitu 0,7. Sehingga instrumen kuesioner pengetahuan umum dinyatakan reliabel karena nilai Cronbach's Alpha melebihi 0,7.

\section{Prosedur Penelitian}

Penelitian ini akan dilakukan didalam ruangan kuliah. Sesi awal yaitu peneliti terlebih dahulu memperkenalkan diri kepada partisipan dan menjelaskan maksud peneliti untuk melakukan penelitian. Peneliti akan meminta kesediaan partisipan untuk mengisi kuesioner penelitian. Sesi 
kedua yaitu pembagian kuesioner kepada partisipan. Kuesioner akan dibagikan secara acak kepada partisipan. Setiap partisipan akan mendapatkan kuesioner dengan perlakuan berbeda. Perlakuan berbeda tersebut merupakan manipulasi dari variabel informasi investasi, yang terdiri dari perlakuan informasi investasi negatif dan informasi investasi negatif. Berbeda halnya dengan variabel overconfidence yang tidak dapat dipastikan untuk membagi ke dalam kelompok eksperimen, sehingga partisipan yang memiliki sifat overconfidence maupun underconfidence hanya dapat diketahui apabila kuesioner telah ditabulasikan.

Selanjutnya partisipan diminta mengisi data demografi dan peneliti akan memberitahu partisipan bahwa data pribadi yang diperoleh dalam penelitian ini akan dijaga kerahasiaannya. Setelah partisipan mengisi data demografi, peneliti selanjutnya akan menjelaskan instruksi pengisian kuesioner. Pada eksperimen ini, semua partisipan akan diposisikan sebagai seorang manajer proyek investasi. Partisipan akan diminta untuk menentukan pilihan apakah akan melanjutkan atau menghentikan sebuah proyek investasi. Partisipan diberi tahu bahwa penelitian ini akan melibatkan pengujian pengetahuan umum dan pengambilan keputusan. Peneliti juga akan memberitahu kepada partisipan untuk tidak melihat isi kuesioner peserta lain selama proses pengerjaan kuesioner.

\section{Pengukuran Variabel}

Variabel depende diukur dengan meminta pendapat peserta atas keputusan melakukan eskalasi komitmen dengan menggunakan skala likert yang terdapat dalam kuesioner A dan B dengan menetapkan poin dalam skala Likert 1-6 (dimana $1=$ menghentikan proyek sampai dengan $6=$ melanjutkan proyek). Variabel independen pertama penelitian ini yaitu informasi investasi. Informasi investasi diukur menggunakan kuesioner yang terdiri dari kuesioner dengan perlakuan informasi investasi positif dan negatif yang memiliki hubungan dengan skenario eskalasi komitmen. Informasi investasi ini menggunakan skala nominal dimana informasi investasi negatif diberi simbol angka 1 dan informasi investasi positif diberi simbol angka 2.

Variabel independen kedua yaitu overconfidene. Overconfidence seorang individu akan ditentukan melalui skor bias dari kuis pengetahuan umum yang telah dijawab oleh partisipan. Partisipan yang overconfidence dan underconfidence akan dikelompokkan berdasarkan skor bias. Skor bias positif mewakili overconfidence, skor bias negatif mewakili underconfidence, dan skor bias nol menunjukkan orang yang dikalibrasi secara akurat. Overconfidence ini menggunakan skala nominal dimana partisipan yang overconfidence diberi simbol angka 1 dan partisipan yang underconfidence diberi simbol angka 2.

\section{HASIL DAN PEMBAHASAN \\ Gambaran Umum Objek Penelitian}

Partisipan dalam penelitian ini adalah mahasiswa program magister Fakultas Ekonomi Universitas Negeri Padang. Mahasiswa magister FE UNP sebagian besar sudah bekerja sehingga bisa dijadikan sebagai proksi manajer. Kuesioner penelitian disebar dalam waktu satu hari pada mahasiswa Magister Manajemen (MM) dan mahasiswa Magister Pendidikan Ekonomi (MPdE).

Total kuesioner yang disebar sebanyak 64 kuesioner dimana 48 kuesioner disebar kepada mahasiswa magister manajemen dan 18 kuesioner disebar kepada mahasiswa magister pendidikan ekonomi. Dari total 64 kuesioner yang disebar, 2 kuesioner tidak dapat diolah karena terdapat kesalahan dalam pengisian kuesioner. Jumlah kuesioner yang digunakan pada penelitian ini hanya kuesioner yang telah diisi dengan lengkap dan sesuai dengan ketentuan. Sebanyak 14 
partisipan laki-laki dan 48 partisipan perempuan ikut serta dalam eksperimen ini. Rata-rata umur partisipan yaitu 26,9 tahun.

\section{Statistik Deskriptif}

Analisis statistik deskriptif antar variabel penelitian bisa dilihat pada Tabel 2 berikut ini:

Tabel 2

Statistik Deskriptif Eskalasi Komitmen

\begin{tabular}{|c|c|c|c|}
\hline \multirow{2}{*}{ Overconfidence } & \multicolumn{2}{|c|}{ Informasi Investasi } & \multirow{2}{*}{ Total } \\
\hline & Negatif & Positif & \\
\hline Overconfidence & $\begin{array}{c}\mathrm{N}=23 \\
M=5,30 \\
S D=0,70\end{array}$ & $\begin{array}{c}\mathrm{N}=24 \\
M=3,33 \\
S D=1,93\end{array}$ & $\begin{array}{c}\mathrm{N}=47 \\
M=4,49 \\
S D=1,47\end{array}$ \\
\hline Underconfidence & $\begin{array}{c}\mathrm{N}=7 \\
M=4,86 \\
S D=1,35\end{array}$ & $\begin{array}{c}\mathrm{N}=8 \\
M=4,13 \\
S D=1,36\end{array}$ & $\begin{array}{c}\mathrm{N}=15 \\
M=4,27 \\
S D=1,34\end{array}$ \\
\hline Total & $\begin{array}{c}\mathrm{N}=30 \\
M=5,20 \\
S D=0,89\end{array}$ & $\begin{array}{c}\mathrm{N}=32 \\
M=3,72 \\
S D=1,49\end{array}$ & \\
\hline
\end{tabular}

(Sumber: Data penelitian yang diolah, 2019)

Sebanyak 30 partisipan mendapatkan informasi investasi negatif dan 32 partisipan mendapatkan informasi investasi positif. Partisipan dengan overconfidence berjumlah 47 orang dan partisipan dengan underconfidence sebanyak 15 orang. Rata-rata untuk kelompok informasi investasi negatif yaitu 5,20 dengan standar deviasi 0,89, sedangkan rata-rata kelompok informasi investasi positif yaitu 3,72 dengan standar deviasi 1,49. Kelompok overconfidence memiliki ratarata sebesar 4,49 dan standar deviasi 1,47. Kelompok underconfidence mempunyai rata-rata 4,27 dan standar deviasi 1,34 .

Hasil ini menunjukkan bahwa manajer yang mendapatkan informasi investasi negatif akan memilih untuk melakukan eskalasi komitmen dan manajer yang mendapatkan informasi investasi positif akan memilih untuk tidak melakukan eskalasi komitmen. Hasil ini juga menunjukkan bahwa manajer overconfidence maupun underconfidence akan memilih untuk melakukan eskalasi komitmen.

\section{Uji Asumsi Klasik}

Pengujian normalitas dalam penelitian ini menggunakan uji statistik Kolmogorov-Smirnov (K-S) dengan ketentuan jika nilai signifikansi >0,05 maka data dapat dikatakan normal. Berdasarkan hasil olah data dari SPSS, didapatkan nilai signifikansi Kolmogorov-Smirnov, untuk variabel informasi investasi sebesar 0,00. Nilai signifikansi Kolmogorov-Smirnov, untuk variabel overconfidence sebesar 0,00. Dengan demikian, baik variabel informasi investasi maupun overconfidence memiliki nilai signifikansi kecil dari 0,05. Hasil ini menunjukkan bahwa data tidak terdistribusi secara normal.

Pengujian homogenitas dilakukan dengan cara membandingkan nilai sig. pada Levene's Statistic. Kriteria pengujian homogenitas yaitu jika nilai signifikansi $>0,05$, maka dapat dikatakan bahwa varian data adalah homogen. Hasil olah data untuk uji homogenitas menunjukkan hasil nilai Levene Statistic untuk variabel informasi investasi menunjukkan nilai 38,85 dengan nilai signifikansi sebesar 0,00. Nilai tersebut lebih kecil dari 0,05, maka dapat 
disimpulkan bahwa variabel informasi investasi tidak memiliki varian yang sama. Nilai Levene Statistic untuk variabel overconfidence yaitu 2,23 dengan nilai signifikansi sebesar 0,14 . Nilai signifikansi overconfidence lebih besar dari 0,05, sehingga dapat dismpulkan bahwa variabel overconfidence memiliki varian yang sama.

\section{Uji Hipotesis}

Teknik analisis data yang digunakan untuk menguji kebenaran hipotesis yang diajukan adalah dengan menggunakan analisis uji One Way ANOVA (Analysis of Variance). Analisis One Way ANOVA pada dasarnya bertujuan untuk membandingkan nilai rata-rata yang terdapat pada variabel terikat di semua kelompok yang dibandingkan. Berikut hasil uji One Way ANOVA pada penelitian ini.

Hipotesis pertama $\left(\mathrm{H}_{1}\right)$ memprediksi bahwa manajer yang menerimana informasi investasi negatif akan cenderung melakukan eskalasi komitmen daripada manajer yang menerima informasi investasi positif. Pada Tabel 3 merupakan hasil uji parametrik yang menunjukkan mean square senilai 43,12 dan nilai signifikansi uji analisis One Way ANOVA sebesar $0,00<0,05$. Hal ini membuktikan bahwa manajer yang menerimana informasi investasi negatif akan cenderung melakukan eskalasi komitmen daripada manajer yang menerima informasi investasi positif adalah benar.

Hipotesis pertama memiliki tambahan uji non-parametrik. Uji non-parametrik ini bertujuan untuk kelengkapan hasil penelitian yang yang memiliki data yang tidak berdistribusi normal. Uji non-parametrik yang digunakan adalah uji Kruskal Wallis. Tabel 3 menunjukkan mean rank untuk informasi investasi negatif dan informasi investasi positif yang berbeda yaitu mean rank informasi investasi negatif lebih tinggi dari pada informasi investasi positif sebesar 39,80 dan 23,72. Nilai signifikansi yang ditunjukkan oleh nilai asymp.sig. yang dihasilkan adalah 0,00 dimana lebih kecil dari 0,05. Dengan demikian dari hasil analisis tersebut dapat ditarik kesimpulan bahwa hipotesis pertama $\left(\mathbf{H}_{1}\right)$ terdukung.

Tabel 3

\begin{tabular}{|c|c|c|c|}
\hline \multicolumn{4}{|c|}{$\begin{array}{l}\text { Hasil Uji Hipotesis Parametrik dan Non-Parametrik } \\
\text { One Way ANOVA }\end{array}$} \\
\hline & Mean Square & $\mathrm{F}$ & Sig \\
\hline Informasi Investasi & 43,12 & 20,74 & 0,00 \\
\hline Overconfidence & 0,32 &, 12 &, 75 \\
\hline \multicolumn{4}{|l|}{ Kruskal Wallis } \\
\hline & & Mean Rank & $\begin{array}{l}\text { Asymp. } \\
\text { Sig. }\end{array}$ \\
\hline \multicolumn{2}{|c|}{ Informasi Investasi Negatif } & 39,80 & \multirow{2}{*}{0,00} \\
\hline \multicolumn{2}{|c|}{ Informasi Investasi Positif } & 23,72 & \\
\hline \multicolumn{2}{|c|}{ Overconfidence } & 31,51 & \multirow{2}{*}{0,99} \\
\hline \multicolumn{2}{|l|}{ Underconfidence } & 31,47 & \\
\hline
\end{tabular}

(Sumber: Data penelitian yang diolah, 2019)

Hipotesis pertama $\left(\mathrm{H}_{2}\right)$ memprediksi bahwa manajer dengan overconfidence akan cenderung melakukan eskalasi komitmen daripada manajer dengan underconfidence. Pada Tabel 3 merupakan hasil uji parametrik yang menunjukkan mean square senilai 0,32 dan nilai signifikansi uji analisis One Way ANOVA sebesar 0,74>0,05. Dengan demikian, dapat diambil kesimpulan baik manajer overconfidence maupun underconfidence akan cenderung melakukan eskalasi komitmen. 
Hipotesis kedua juga memiliki tambahan uji non-parametrik. Tabel 3 menunjukkan mean rank untuk overconfidence dan underconfidence yaitu sebesar 31,51 dan 31,47. Nilai signifikansi yang ditunjukkan oleh nilai asymp.sig. yang dihasilkan adalah 0,99 dimana lebih besar dari 0,05. Dengan demikian dari hasil analisis tersebut dapat ditarik kesimpulan bahwa hipotesis pertama (H2) tidak terdukung.

\section{Pembahasan}

Hasil uji hipotesis dengan One Way ANOVA, menunjukkan bahwa variabel informasi investasi memiliki nilai signifikansi 0,00 . Nilai signifikansi tersebut $<0,05$, sehingga dapat diambil kesimpulan bahwa informasi investasi berpengaruh signifikan terhadap eskalasi komitmen. Hal ini mendukung hipotesis pertama.

Hasil penelitian ini sesuai dengan teori prospek yang menjelaskan bahwa ketika manajer menerima informasi yang dibingkai secara negatif dalam bentuk pilihan antara kerugian pasti yang telah terjadi dengan kerugian dimasa mendatang yang kurang pasti, maka manajer cenderung menanggung risiko (risk seeking) dengan memilih kerugian di masa mendatang yang kurang pasti dengan harapan kelak mendapat pengembalian yang positif dengan risiko menambah dana dan berharap mendapat pengembalian positif. Sehingga hal tersebut membuat manajer melakukan eskalasi komitmen. Sedangkan ketika manajer menerima informasi yang dibingkai secara positif maka keputusan yang diambil akan cenderung menolak risiko (risk averse). Manajer akan memandang keputusan selanjutnya sebagai kerugian yang pasti terjadi sehingga tidak menambah investasi dengan tidak melakukan eskalasi komitmen.

Hasil penelitian ini konsisten dengan penelitian yang dilakukan Dewanti (2010), Salter et al. (2013), serta Sari dan Wirakusuma (2016) yang menunjukkan hasil bahwa informasi investasi yang dibingkai secara negatif cenderung membuat manajer untuk melakukan tindakan eskalasi komitmen. Penelitian ini tidak sejalan dengan penelitian yang dilakukan oleh Amelia (2014), Rita dan Sari (2012), serta Dwita (2007) yang memberikan hasil yang sebaliknya, yaitu framing negatif atas informasi investasi tidak memiliki pengaruh dalam keputusan untuk melakukan eskalasi komitmen.

Hasil uji hipotesis dengan One Way ANOVA, menunjukkan bahwa variabel overconfidence memiliki nilai signifikansi 0,74 . Nilai signifikansi tersebut $>0,05$, sehingga dapat diambil kesimpulan bahwa overconfidence tidak berpengaruh signifikan terhadap eskalasi komitmen. Hal ini tidak mendukung hipotesis kedua. Hasil pada penelitian ini tidak sejalan dengan Tine (2013) dan Ronay et al. (2016) yang menunjukkan hasil bahwa manajer overconfidence akan memilih untuk melakukan eskalasi komitmen.

Kartini dan Nugraha (2015) menyatakan bahwa orang yang overconfidence lebih memandang suatu risiko itu rendah dan orang yang underconfidence lebih memandang suatu risiko itu tinggi. Jika dilihat pada kasus eskalasi komitmen yang diberikan kepada partisipan, didalamnya telah memasukkan skenario informasi investasi. Partisipan yang mendapat kasus eskalasi komitmen dengan skenario informasi investasi negatif akan memandang suatu risiko rendah dengan meningkatkan komitmen. Sehingga ketika didapatkan skor bias dari kuis pengetahuan umum yang dilakukan partisipan menunjukkan partisipan underconfidence, hal tersebut menyebabkan pengaruh overconfidence seseorang terhadap eskalasi komitmen menjadi terganggu karena adanya perlakuan informasi investasi pada kasus eskalasi komitmen. Hal ini menyebabkan, partisipan yang underconfidence memilih untuk tetap melakukan eskalasi komitmen. 
Wulandari dan Iramani (2014) dalam penelitiannya tidak menemukan hubungan overconfidence dalam pengambilan keputusan investasi, hal tersebut disebabkan karena overconfidence tidak selalu menjadi salah satu faktor yang mempengaruhi seseorang dalam mengambil keputusan. Overconfidence merujuk pada persepsi seseorang terhadap kompetensi yang dimilikinya dalam mengatur dan melakukan tindakan. Dengan kata lain, rasa percaya diri merupakan penilaian subyektif terhadap kemampuan seseorang dalam situasi pengambilan keputusan. Sehingga dapat disimpulkan jika pada penelitian ini menyatakan bahwa overconfidence tidak mempengaruhi pengambilan keputusan eskalasi komitmen karena masingmasing individu memiliki persepsi yang berbeda-beda. Selain itu jumlah partisipan overconfidence jauh berbeda dengan jumlah partisipan underconfidence. Hal ini dikarenakan ketika partisipan mengisi kuis pengetahuan umum ada yang mencoba mencari jawaban menggunakan Google atau search engine. Sehingga hal tersebut menyebakan bias terhadap hasil penelitian.

\section{SIMPULAN, KETERBATASAN, DAN SARAN Kesimpulan}

Penelitian ini bertujuan untuk menguji pengaruh informasi investasi dan overconfidence dalam memengaruhi keputusan manajer terkait eskalasi komitmen. berdasarkan argumen teori prospek, penelitian ini memprediksi bahwa manager dengan informasi investasi negatif akan cenderung memutuskan untuk melakukan eskalasi komitmen. Sebaliknya, manager dengan informasi investasi positif akan cenderung memutuskan untuk tidak melakukan eskalasi komitmen.

Penelitian ini juga menguji pengaruh overconfidence seorang manajer terhadap eskalasi komitmen. Penelitian ini memprediksi bahwa manajer yang overconfidence akan memilih untuk melakukan eskalasi komitmen, dan sebaliknya manajer yang underconfidence tidak akan melakukan eskalasi komitmen.

Penelitian ini menunjukkan bahwa terdapat perbedaan eskalasi komitmen pada kelompok manajer yang diberi informasi investasi negatif dengan kelompok manajer yang diberi informasi investasi positif. Hasil uji hipotesis menunjukkan bahwa, manajer dengan informasi investasi negatif cenderung memutuskan untuk melakukan eskalasi komitmen. Namun penelitian ini tidak berhasil membuktikan perbedaan eskalasi komitmen pada kelompok manajer overconfidence dengan kelompok manajer underconfidence. Hasil uji hipotesis menunjukka bahwa, manajer overconfidence maupun underconfidence sama-sama memilih untuk melakukan eskalasi komitmen.

\section{Keterbatasan}

Penelitian ini memiliki sejumlah keterbatasan dimana kasus dalam eksperimen ini disajikan dalam bentuk ilustrasi yang merupakan penyederhanaan dari situasi dan kondisi di dunia nyata. Sehingga kasus yang disajikan dalam instrumen eksperimen belum mencerminkan secara penuh kasus yang terjadi di lapangan. Waktu pelaksanaan eksperimen yang berbeda dikarenakan penyesuaian jadwal mata kuliah dari kelas partisipan dan pengambil keputusan (manajer) yang digunakan sebagai proksi dalam penelitian ini adalah mahasiswa.

\section{Saran}

Saran yang dapat diberikan untuk penelitian masa depan yaitu peneliti selanjutnya diharapkan agar dapat lebih bisa mengontrol partisipan eksperimen untuk tidak memegang hp atau laptop sehingga tidak mencari jawaban terkait kuis pengetahuan umum. Penelitian masa depan 
sebaiknya menggunakan manajer asli sebagai subjek penelitian agar menunjukkan peningkatan kemiripan keadaan yang sebenarnya. Penelitian selanjutnya sebaiknya melakukan pengujian terhadap karakteristik individu seperti kejujuran, religiusitas, dan tanggung jawab.

\section{DAFTAR PUSTAKA}

Almilia, L.S., Wulanditya, P. (2016). The Effect of Overconfidence and Experience on Belief Adjustment Model in Investment Judgement. International Research Journal of Business Studies, 9(1):39-47.

Amelia, Y. (2014). Framing Effect sebagai Determinan Eskalasi Komitmen Manajer dalam Keputusan Investasi: Dampak dari Latar Belakang Pendidikan Akuntansi dan Non Akuntansi. Jurnal Ilmiah Gema Ekonomi, 4(2):467-480.

Anderson, C., Brion, S., Moore, D.A., Kennedy, J.A.(2012). A Status-Enhancement Account of Overconfidence. Journal of Personality and Social Psychology.

Brockner, J. (1992). The Escalation of Commitment to A Failing Course of Action: Toward Theoretical Progress. Academy of Management Review, 17(1): 36-91.

Bazerman, H., Moore, D.A. (2013). Judgment in Managerial Decision Making. Eight Edition. America:John Wiley \& Sons, Inc.

Chang, Y.L., Coyte, R., Cheng, M.M. (2018). Is a Fresh of Eyes Always Better? The Effect of Consultant Type and Assigned Task Purpose on Communicating Project Escalation Concerns. Management Accounting Review.

CNBC Indonesia. (2019). Rawan Korupsi, Proyek Hambalang Lanjut.Diakses dari https://www.cnbcindonesia.com/news/20190805213149-8-90037/rawan-korupsi-proyekhambalang-lanjut

Dewanti, R. (2010). Pengaruh Negative Framing dan Job Rotation pada Kondisi Adverse Selection terhadap Eskalasi Komitmen. Skripsi. Fakultas Ekonomi. Universitas Diponegoro: Semarang.

Dwita, S. (2007). The Influence of Adverse Selection and Negative Framing on Escalation of Commitment In Project Evaluation Decisions. SNA X Makassar.

Eveline, F. (2010). Pengaruh Adverse Selection, Pembingkaian Negatif, dan Self Efficacy terhadap Eskalasi Komitmen Proyek Investasi Yang Tidak Menguntungkan. Jurnal Akuntansi dan Manajemen, 21(2):77-94.

Fokufuka, P., Fargher, N., Wang, Z. (2014). The Influence of Sunk Costs, Personal Responsibility and Culture on The Tendency of Accountants to Facilitate Escalation of Commitment. Pacific Accounting Review, 26(3):374-391.

Prasetyo, A. (2016).Alasan Proyek Hambalang Tidak Layak Dilanjutkan".GresNews.com. Diakses dari http://www.gresnews.com/berita/hukum/104307-alasan-proyek-hambalangtidak-layak-dilanjutkan/

Harrel, A., Harrison, P. (1994). An Incentive to Shirk, Privately Held Information, and Managers' Project Evaluation Decisions. Accounting, Organization and Society, 19(7):569577.

Helmayunita, N. (2015). Pengaruh Adverse Selection, Kontrol Monitoring, dan Penalaran Moral Individu terhadap Perilaku Eskalasi Komitmen. Jurnal WRA, 3(1):513-528.

Jackson, A.T. et al. (2018).The Reciprocal Relationships Between Escalation, Anger, and Confidence in Investment Decisions Over Time. Frontiers in Psychology, 9. 
Kartikasari, N., Subroto, B., Rahman, A.F. (2013). Perbedaan Tujuan Auditor atas Tingkat Overconfidence Pertimbangan Auditor (Studi Eksperimental. Ekuitas: Jurnal Ekonomi dan Keuangan, 17(2):234-255.

Kartini, Nugraha, N.F. (2015). Pengaruh Illusions of Control, Overconfidence dan Emotion terhadap Pengambilan Keputusan Investasi pada Investor di Yogyakarta. Jurnal Inovasi dan Kewirausahaan, 4(2):115-123.

Kufepaksi, M. (2010). Investor Overconfidence dalam Penilaian Saham: Perspektif Gender dalam Eksperimen Pasar. Kinerja, 14(2):131-150

Kennedy, J.A., Anderson, C., Moore, D.A. (2013).When overconfidence is revealed to others: Testing the status-enhancement theory of overconfidence. Organizational Behavior and Human Decision Processes, 122:266-279.

Koroy, T.R. (2008). Pengujian Efek Pembingkaian Sebagai Determinan Eskalasi Komitmen dalam Keputusan Investasi: Dampak dari Pengalaman Kerja. Simposium Nasional Akuntansi XI Pontianak.

Liang, B., Kale, S.H., Cherian, J. (2014). Is The Future Static or Dynamic? The Role of Culture on Escalation of Commitment in New Product Development. Industrial Marketing Management, 43:155-163.

Meikle, N.L., Tenney, E.R., Moore, D.A. (2016). Overconfidence at work: Does overconfidence survive the checks and balances of organizational life?. Research in Organizational Behavior.

Michailova, J., Katter, J.K.Q. (2014). Quantifying Overconfidence in Experimental Finance. Journal Behavioural Accounting and Finance, 4(4):351-367.

Mulia, T.W., Lodovicus, L., Widjanarko, T.A. (2015). Pengaruh Hurdle Rates dan Framing Terhadap Eskalasi Komitmen dalam Penganggaran Modal.

Nasution, S.Z.H. (2018). Pengaruh Adverse Selection dan Negative Framing terhadap Eskalasi Komitmen dalam Pengambilan Keputusan Investasi. Skripsi. Fakultas Ekonomi dan Manajemen. Institut Pertanian Bogor: Bogor.

Nugraha, K.S.P. (2015). Pengaruh Monitoring Control Dan Kondisi Adverse Selection Terhadap Eskalasi Komitmen Pengambilan Keputusan Investasi Dengan Gender Dan Locus Of Control Sebagai Variabel Pemoderasi. Skripsi. Fakultas Ekonomi. Universitas Negeri Yogyakarta: Yogyakarta.

Pikulina, E., Renneboog, L., Tobler, P.N. (2017). Overconfidence and Invetment: An Experimental Approach. Journal of Corporate Finance, 43:175-192.

Rita, M.R., Sari, M.P. (2012). Pengaruh Adverse Selection dan Negative Framing terhadap Eskalasi Komitmen. Eco-Entrepreneurship Seminar \& Call Paper "Improving Performance by Improving Environment.

Ronay, R., Oostrom, J.K., Willenbrock, N.L., Vugt, M.V. (2016). Pride Before The Fall: (Over) Confidence Predicts Escalation of Public Commitment. Journal of Experimental Social Psychology.

Russo, J.E., Schoemaker, J.H. (2016). Overconfidence. The Palgrave Encyclopedia of Strategic Management.

Sari, N.K.A.P., Wirakusuma, M.G. (2016). Pengaruh Adverse Selection dan Negative Framing pada Kecenderungan Eskalasi Komitmen. E-Jurnal Ekonomi dan Bisnis Universitas Udayana, 5(3):573-600.

Salter, S.B., Sharp, D.J.(2004). The Determinants of Escalation of Commitment: National Culture and Experiences Effects. 
Salter, S.B., Sharp, D.J., Chen, Y. (2013). The Moderating Effects of National Culture on Escalation of Commitment. Advances in Accounting, Incorporating Advances in Internasional Accounting, 29:161-169.

Santoso, A. B. (2012). Peranan Locus of Control, Self-Set Dan Organizational Set-Hurdle Rates Terhadap Eskalasi Komitmen Pada Level Pengambilan Keputusan Penganggaran Modal. Jurnal Ilmiah Mahasiswa Akuntansi, 1(3).

Sharp, D.J., Salter, S.B. (1997). Project Escalation and Sunk Costs: A Test of The Internasional Generalizability of Agency and Prospect Theories. Journal of Internasional Business Studies, 28(1):101-122.

Soma, A.A., Restuti, M.I.M.D. (2017). Pengaruh Informasi Investasi, Job Rotation dan Kondisi Adverse Selection Terhadap Eskalasi Komitmen. SNA XX Jember.

Staw, B. M. (1976). Knee-Deep in The Big Muddy: A Study of Escalating Commitment to A Chosen Course of Action. Organizational Behavior and Human Performance, 16:27-44.

Staw, B. M., Ross, J. (1980). Commitment in an Experimenting Society: A study of the Attribution of Leadership From Administrative Scenarios. Journal of Applied Psychology, 65(3):249-260.

Staw, B.M. (1981). The Escalation of Commitment To a Course of Action. Academy of Management Review, 6(4):577-587.

Sugiyono. (2017). Metode Penelitian Kombinasi. Bandung: Alfabeta.

Tine, D.C. (2013). Attribution Bias and Overconfidence in Escalation of Commitment: The Role of Desire to Rectify Past Outcomes. Dissertation. Georgia State University.

Trinugroho, I., Sembel, R. (2011). Overconfidence and Excessive Trading Behavior: An Experimental Study. International Journal of Business and Management, 6(7):147-152.

Whyte, G. (1986). Escalating Commitment to a Course of Action: A Reinterpretation. The Academy of Management, 11(2):311-321.

Wulandari, D.A., Iramani, R. (2014). Studi Experienced Regret, Risk Tolerance, Overconfidence dan Risk Perception pada Pengambilan Keputusan Investasi Dosen Ekonomi. Journal of Business and Banking, 4(1):55-66. 